\title{
ESTIMATING JUNIOR SCHOOL-AGE CHILDREN'S MASTERY OF COMPLEX MOVEMENTS APPLYING PARAMETRIC TEACHING
}

\author{
Rima Bakienè \\ Lithuanian Academy of Physical Education, Kaunas, Lithuania
}

\begin{abstract}
Rima Bakienė. PhD in Social Sciences (Education), Lecturer at the Department of Sports Games, Lithuanian Academy of Physical Education.
\end{abstract} Research interests: physical education, sports, motor control.

\begin{abstract}
After realizing the fact that learning new movements and actions is efficient only in the case when the child is capable of applying the movement or action learnt under new conditions, when the skill acquired is remembered and retained for long the authors (Schmidt, 1988, 1991; Schmidt, Lee, 1999; Skurvydas, 1998; Skurvydas, Gedvilas, 2000) have singled out and defined the parametric teaching of movements. Therefore the following research problem arises: is the parametric method of teaching effective in teaching children of junior school-age to perform complex movements and actions, as well as to retain them for long and apply them under new conditions. The aim of the research was to establish and estimate the efficiency of the parametric method and mastery in teaching children of the junior schoolage the accuracy of movements, retaining power and creativity of the complex movements learnt. With a view to find out the efficiency of parametric teaching a pedagogical experiment with junior schoolchildren $(n=67)$ aged $8-10$ years was carried out. During all teaching stages the program of the movements taught was applied in the period of 7-8 weeks. In this period the observation of the development of mastering new movements in the standard teaching group and in that of parametric teaching took place. During the following 2 months the efficiency of standard and parametric teaching applied was observed, i. e. the ability to retain the movements learnt for as long as possible.

We can conclude that the more relatively complicated movements and actions are taught the less difference between efficiency of standard teaching and parametric teaching is found: when teaching complicated accuracy requiring movements using both standard and parametric methods, development and level of mastering are adequate; when teaching complicated locomotive movements, the children of standard teaching group master the movements more rapidly; when teaching complicated high accuracy requiring combinations of locomotive movements under standard and variable conditions, the indices of development of mastering did not differ essentially.

The children of standard and parametric teaching groups retained and reproduced (after 1 and 2 months) complicated movements of different degree of complexity in a different way: the children who had been taught under variable conditions markedly better retained and reproduced both complicated locomotive and complicated locomotive movements requiring accuracy; the children of parametric teaching groups who had been taught the same movements and their combinations under conditions of change in parameters of high degree, better retained and reproduced the movements than the children of other parametric teaching groups.

The efficiency of standard and parametric teaching of complicated movements for children's abilities to retain them for a longer period of time, reproduce and apply them in new circumstances - creativity of movements - depends on the character of the circumstances changed: the children of parametric teaching groups in new circumstances by a long way better retained and reproduced movements previously learnt which were complicated locomotive ones when structure of a movement was altering and necessity to make a choice existed.
\end{abstract}

Keywords: parametric teaching, teaching children under standard and variable conditions, junior school-age (8-10 years).

\section{INTRODUCTION}

$\mathrm{T}$ opicality of research. One of the basic research objects in the theory and didactics of physical education is research into the man's movement possibilities, i. e. the whole complex of properties and qualities of the human organism enabling the individual to perform movements and actions of the quantitative and qu- alitative parameters desired (Magill, Hall, 1990, Schmidt, Lee, 1999).

The complexity of answers to the questions concerning learning movements, actions and their combinations, possibilities of their practical application under new, changeable conditions, new movements formation, etc. does not allow the 
researchers to restrict themselves to merely using the traditional methods of teaching movements and actions but requires them to search for new methods based on pedagogics, psychology, physiology and other sciences, as well as to search for the means that would provide a conceptual basis for efficient teaching of complex movements, actions and their combinations of the junior school-age. For these reasons, the research of parametrical teaching of complex movements of the junior school-age is topical.

The problem of the research. After having realized the fact that acquirement of new movements and actions is efficient only in the case when a child is capable of applying the movement or action learnt under new conditions, when the skill acquired is remembered for a long time, the authors (Schmidt, 1988, 1991; Schmidt, Lee, 1999; Skurvydas, 1998; Skurvydas, Gedvilas, 2000) singled out and defined the parametric teaching of movements.

Parametric teaching is the mode of teaching movements, actions and their combination by constant alteration of quantitative parameters (distance, direction, etc.), overcoming external (obstacles, the competitor) and internal (fatigue, agitation) resistance.

When applying the parametric method of teaching the children:

- learn the movements more slowly but retain them for a longer period of time (Magil, Hall, 1990; Shea, Kohl, 1991; Jacoby et al., 1994);

- learn and perform a greater number of various movements and actions and thus are capable of applying the movements learnt more effectively under new conditions (Adaškevičienè, 1994; Skurvydas, 1998; Skurvydas, Gedvilas, 200; Dolonec et al., 2002).

The above mentioned propositions are based only on laboratory research while teaching simple, non-complex movements.

Therefore the following research problem arises: is the parametric method of teaching effective in the process of teaching junior schoolchildren to perform complex movements and actions, as well as to retain them for a long period of time and apply them under new conditions.

The object of the research was the efficiency of the parametric method of teaching complex movements and actions on children of junior school-age.

The aim of the research was to establish and estimate the efficiency of the parametric method and mastery in teaching children of the junior school-age the accuracy of movements, retaining power and creativity of the complex movements learnt.

\section{The tasks of the research:}

1. To establish experimentally and to evaluate the efficiency of the standard and parametric methods of teaching movements and the process of learning complex movements.

2. To study the efficiency of the standard and parametric methods of teaching for retaining the power of complex movements.

3. To establish and estimate the efficiency of the standard and parametric teaching methods for the performance of learned movements under new conditions.

The novelty of the research. By now theoretical propositions and conclusions concerning the parametrical teaching of movements have been based on the study of simple, not complicated movements observed under laboratory conditions.

We investigated complex movements and actions studied under natural conditions with the help of new methodology:

- the main method used in the research was a multi-stage pedagogical experiment;

- the parametric method of teaching complex movements created by Schmidt $(1988,1991)$ was modified by us, both altering the outer parameters of movements (direction, distance, etc.) as well as the inner conditions (the state of fatigue);

- our research was a complex one. The process of learning complex movements and actions, retaining the power, i. e. the ability to recall and reconstruct the movements and actions learnt, creative mastery, i. e. the ability of children to apply the movements learnt under new conditions;

- both average and individual indices and their changes were established and evaluated by our research.

The practical importance of the results of the research. Under the conditions of the ever increasing lack of physical activity and physical fitness with accompanying health problems in the group of children of the junior school-age the efficient learning of complex movements, being able to retain, reconstruct and apply the movements learnt under new conditions is of extreme importance, as it opens great opportunities for children to learn fast to play their favourite games thus 
satisfying the inborn desire of children for action and playing games.

The results of our research is one of the efficient ways to raise the child's motivation for increasing his/her physical activity, as well as an excellent means for improving physical fitness and strengthening health in the group of the junior school-age children.

\section{Methods of the research:}

1. Analysis of scientific literature.

2. Pedagogical experiment.

3. Testing.

4. Methods of mathematical analysis.

Pedagogical experiment. Three classes (groups) of schoolchildren participated in the pedagogical experiment: a control one and two experimental ones. The control group was a group of standard teaching and two experimental groups were those of parametric teaching. The group of standard teaching was taught new complicated movements using the standard method during the lessons of physical education (in all the stages of the experiment). The essence of this teaching is as follows: new movements are being taught under standard conditions, i. e. when the child is being taught one movement or action repeating it permanently, and attentively, and efforts are being made towards the fulfillment of one task. The child does not need to choose anything and nobody interferes with him.

The first and the second groups of parametric teaching were taught new movements using the parametric teaching method. The essence of this method is as follows: new movements are being taught under variable conditions, i. e. when movements and parameters of performance of movements (distance, direction etc.) alter and the children have to overcome an outer resistance (obstacles, an opponent) and make decisions or to be in the state of slight weariness, etc.

The experiment was carried out in three stages:

1. Teaching complicated movements that require accuracy (performing a set shot).

2. Teaching complicated locomotive movements (driving a ball).

3. Teaching locomotive movements requiring high accuracy (performing a lay-up shot in driving).

The first stage of the experiment. All the three groups had performed the same initial test prior to the experiment and the purpose of this test was to evaluate the preparedness of all the three groups surveyed before starting the experiment.
The initial test was performed under standard conditions: $(5 \times 10$ series $=50$ throws $)$, and the throws were performed from the free throw line.

During the experiment the group of standard teaching were performing ball throwing exercises under standard conditions $(5 \times 10$ series $=50$ throws). Throws were performed from the free throw line at the distance of $4 \mathrm{~m}$.

The first group of parametric teaching were performing throwing exercises in the state of slight weariness $(25 \times 2$ series $=50$ throws $)$. The throws were performed from the free throw line, from the same position as were those of the control group.

The second group of parametric teaching were performing ball throwing into the basket under variable conditions $(5 \times 10$ series $=50$ throws $)$. The throws were performed from five different positions at the distance of $4 \mathrm{~m}$ from the basket: $0^{\circ} ; 45^{\circ} ; 90^{\circ} ; 45^{\circ} ; 0^{\circ}$

During all teaching stages the program of the movements taught was applied in the period of $7-8$ weeks. In this period the observation of the development of mastering new movements in the standard teaching group and in that of parametric teaching took place. During the following 2 months the efficiency of standard and parametric teaching applied was observed, i. e. the ability to retain the movements learnt for as long as possible. For that reason in 1 and 2 months the children of those three groups were tested again when applying the same tests and one additional new test. A new test (new circumstances) was the same for all the groups, and using it the creativity of children was established, i. e. how they can apply movements learnt under new circumstances - shot a ball into the basket from 5 different positions (1, $3,4-4 \mathrm{~m}, 2$ and $5-3 \mathrm{~m}$ ).

After the experiment, i. e. after 20 lessons, the children were given usual physical education lessons according to the secondary school programme without any basic basketball movements (actions).

The scheme of the progress of the first stage of the experiment is shown in Fig. 1.

All the children of the three groups were performing the throws into baskets of $260 \mathrm{~cm}$ high and were throwing mini basket balls (450 g).

The second stage of the experiment. Initial testing. Prior to the experiment all the three groups had performed the same initial test of ball driving under standard conditions: dribbling a ball to the centre-line of the court, with the right hand forward and then with the left hand backward. 
Fig. 1 The scheme of the first stage of the experiment
Fig. 2. The scheme of the progress of the second stage of the experiment
Fig. 3. The scheme of the progress of the third stage of the experiment

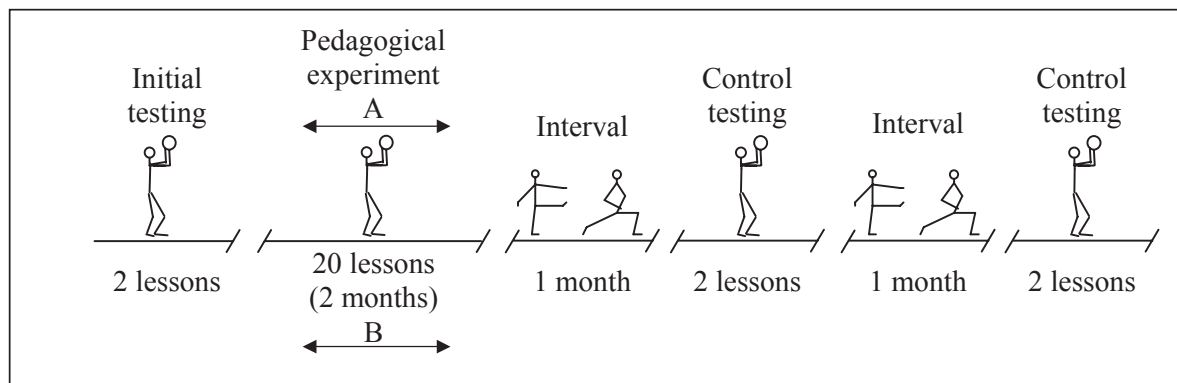

Note. $\stackrel{\mathrm{A}}{\longrightarrow}$ - teaching under standard conditions; $\stackrel{\mathrm{E}}{\longrightarrow}$ - teaching under variable conditions; (interval — physical education lessons given according to the secondary school programme).

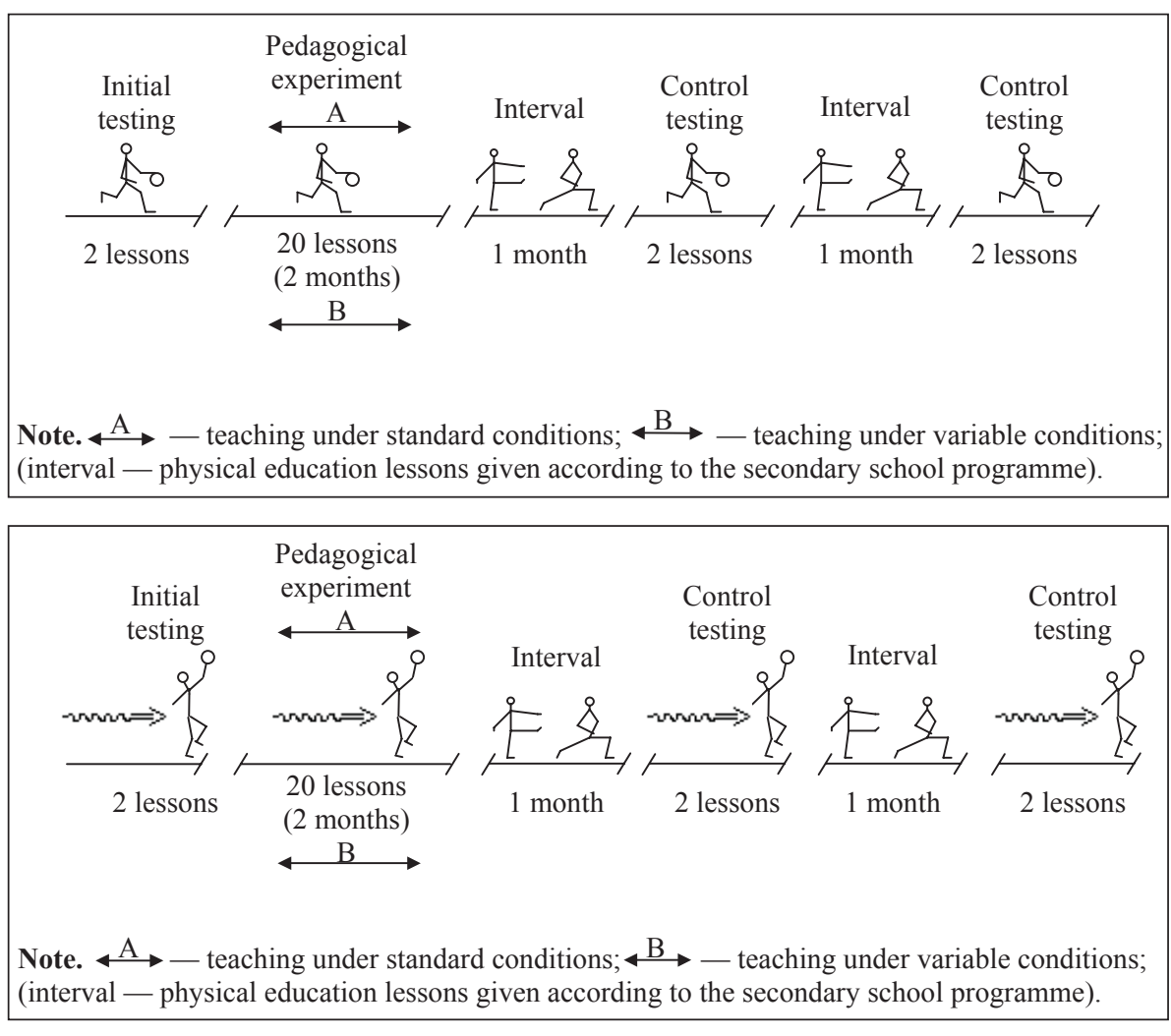

The standard teaching group were driving a ball in pendulous way under standard conditions: forward with the left and backward with the right hand without any interference with them.

The first group of parametric teaching were driving the ball under more complicated conditions requiring certain estimation of the situation and choosing actions among obstacles: on one side of the court there were 5 obstacles located every $2.5 \mathrm{~m}$. The ball was to be dribbled with the hand which was further away from the obstacle.

The second group of parametric teaching were driving a ball among 5 obstacles under variable conditions when qualitative parameters (movement direction, driving hand, additional obstacles) of the exercise being performed were altering (complexity of the task). The obstacles were loca- ted at different sides of the court and when driving back it was necessary to dribble the ball running along the bench.

A new situation was the same for three groups. Performance of the movements was under variable conditions: driving a ball changing the direction of movement and the hand.

The scheme of the progress of the second stage of the experiment is shown in Fig. 2.

The third stage of the experiment. Initial testing. The children were standing at the distance of $8 \mathrm{~m}$ from the basket, then they were driving the ball and performing a lay-up shot, driving forward with the right hand and driving backward with the left hand:

The group of standard teaching were driving the ball and performing a lay-up shot, as they were doing during initial testing. 
The first group of parametric teaching were learning to drive and perform a lay-up shot under variable conditions: when running forward, the ball was being dribbled among obstacles (5 obstacles in every $2.5 \mathrm{~m}$ ) with the hand which was further away from the obstacle, then a lay-up shot was performed and the left hand was being used when driving backward.

The second group of parametric teaching were learning to drive the ball and to perform a lay-up shot in the state of certain weariness. The ball was being driven among obstacles ( 5 obstacles in every $2.5 \mathrm{~m}$ ) and the exercise was repeated 2 times in succession.

A new situation which was the same for the three groups: the children were standing at the distance of $8 \mathrm{~m}$ from the basket (Fig. 3), then, after driving the ball, they were performing a lay-up shot, catching with the left hand, driving the ball around the obstacle, performing a lay-up shot, catching a rebound ball (performing a successful throw) again, driving it with the right hand around another obstacle and throwing into the basket.

The scheme of the progress of the third stage of the experiment is shown in Fig. 3.

Physical education lessons were given 3 times a week.

Testing. During all the stages of the experiment, prior to starting teaching new complicated movements, initial testing had been carried out, during which the level of all the children surveyed had been evaluated prior to the experiment.

During the first stage of the experiment, while learning complicated movements requiring accuracy (performing a set shot), the efficiency of teaching (learning) was evaluated by qualitative (regularity of throwing) and quantitative (accurate throws) indices. If throwing was not an accurate action, a throw was not scored. During each lesson all the participants of the experiment performed 50 throws each and the results of the performance (mastering the movements) were documented (20 times during the experiment in total).

During the second and the third stages of the experiment, while establishing the mastery of new complicated locomotive movements requiring accuracy, some data were being established: the time spent during the testing (s), technical errors (irregular driving of the ball, dispossessed balls, driving not with the hand demanded) and their number. The results of the performance of the movements of all the children participating in the experiment, were documented during every lesson (20 times during the experiment in total), taking the better result of the two.

Methods of mathematical analysis. When processing the results of the testing and establishing the statistical reliability of the difference in the increase of average testing indices, the Stjudent's $t$ test was applied to even-numbered samples.

The relationship between the position of the sample and dispersion characteristics was calculated by applying the STATISTICA program for Windows. The results of statistical analysis of the data are given in Tables and Graphic representations. The graphic representations were drawn applying the Microsoft Excel program, and the tables and the text were performed using Microsoft Word program.

Research participants. The sample studied included 67 ( 35 boys and 32 girls) third formers (the average age $9 \pm 0.5 \mathrm{SK}$ ). We applied the cluster method of choosing the sample surveyed, when the main unit of selection was a class. When performing the experimental study, the choice of individuals at random was not suitable. We chose a secondary school in the city of Kaunas, the only one where 3 lessons a week of physical education were given. And that was one of the conditions of the experiment. In this school two classes were chosen randomly from three parallel classes. They were considered as impact classes $(\mathrm{n}=22$ and $\mathrm{n}=22)$ and the third class was a control one $(n=23)$.

In addition, according to the results of the initial testing, we estimated the minimum of cases applying the reliability of $95 \%$ and the accuracy of succesful throws of 1.5 times when performing the test of throwing into the basket. The sample calculated in such manner consisted of 54 cases.

Research organization. The experiment was started on October 3, 2000: the first stage was carried out from 03-10-2000 to 30-01-2001, the second stage - from 03-02-2001 to 02-06-2001 and the third stage was carried out from 01-102001 to 25-02-2002. The experiment was finished on February 5, 2002.

\section{RESEARCH RESULTS}

The progress of mastering complicated movements when applying the standard and parametric teaching methods

Teaching complicated movements requiring great accuracy (performing a set shot). During 
Fig. 4. The indices of the development of mastering movements performing a set shot in the standard teaching group and the first parametric teaching group

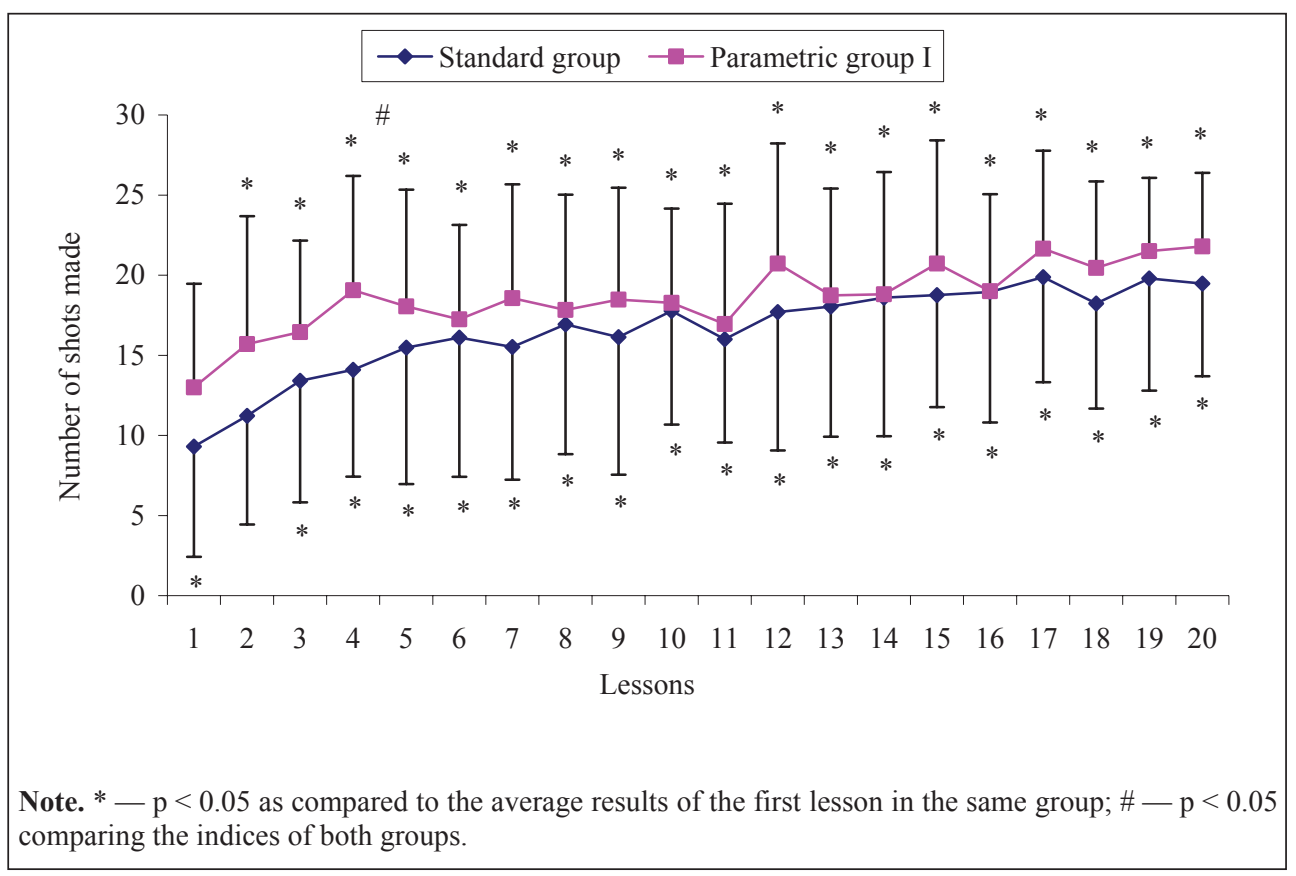

Fig. 5. The indices of the development of mastering movements performing a set shot in the standard group and the second group of parametric teaching

Note. * $-\mathrm{p}<0.05$ compared to the average results of the first lesson in the same group.

the first stage of the pedagogic experiment when teaching complicated movements requiring high accuracy (performing a set shot) both using the standard method (in standard conditions) and parametric method (under the state of slight weariness), when there is no alteration in the character of movements performed and in outer parameters, the development of the performance when evaluating the accuracy of a movement (qualitative indices) was adequate (Fig. 4), however starting with Lesson 8 the increase in these indices $(p<0.05)$ differed statistically significantly in favour of the group of standard teaching.

When teaching the same movements (performing a set shot) using the parametric teaching with altering outer parameters of movements (the position of throwing) the indices of the development of mastering movements of the children (improvement in accuracy) in the essence were not different from those of the standard group children. The average indices of testing in both groups of different teaching starting as early as the second lesson significantly $(p<0.05)$ differed in comparison with the average index of testing in the first lesson (Fig. 5).

The efficiency of teaching complicated movements under standard and variable conditions for stability of movements

Teaching complicated locomotive movements (dribbling a ball). The indices of testing stability of complicated locomotive movements or actions learnt (driving a ball) (both quantitative and qua- 


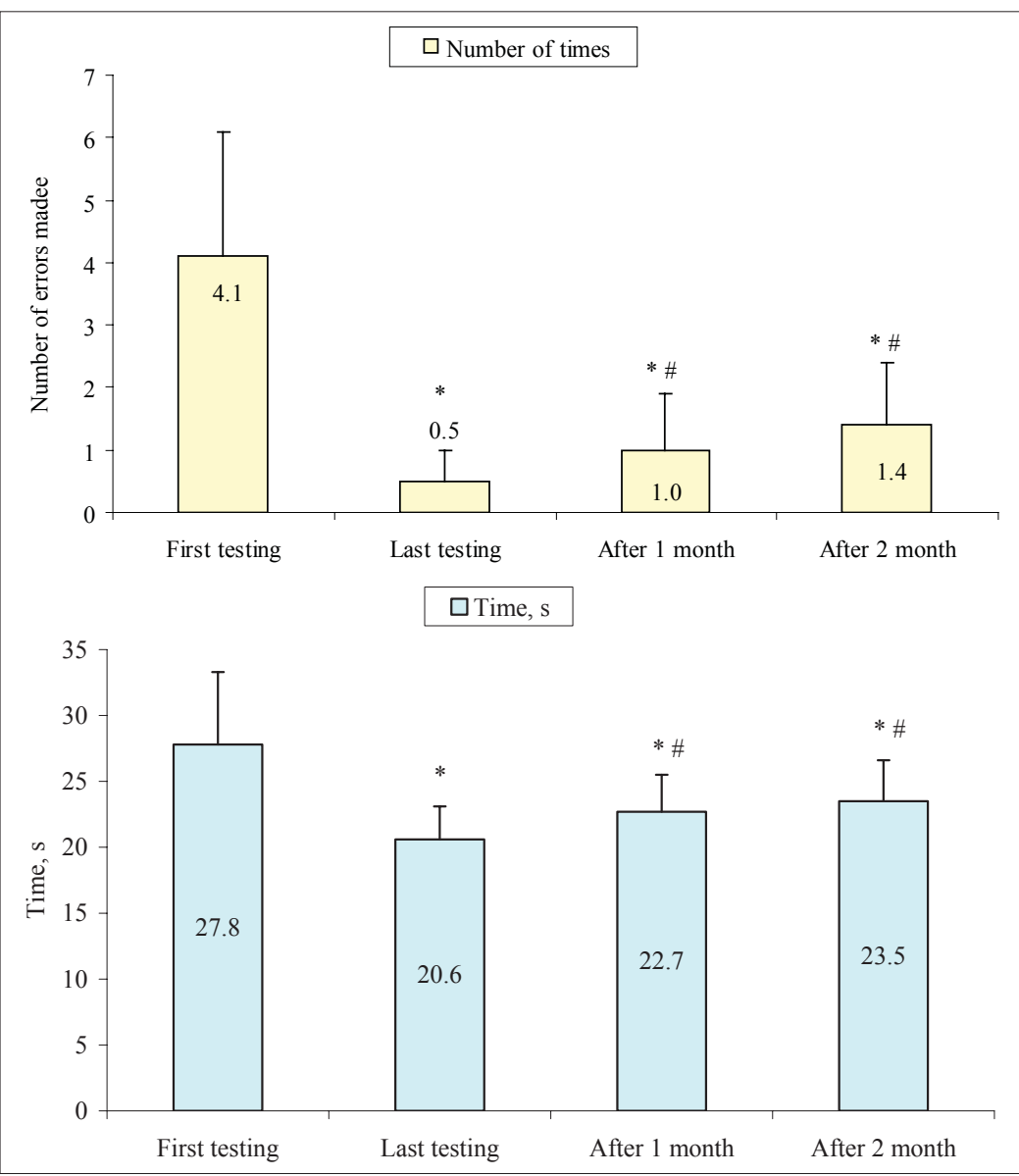

Fig. 6. The indices of stability of mastering dribbling a ball in the group of standard teaching

Note. * $-\mathrm{p}<0.05$ compared to the average results of the first testing; \#- $\mathrm{p}<0.05$ compared to the average results of the last testing.

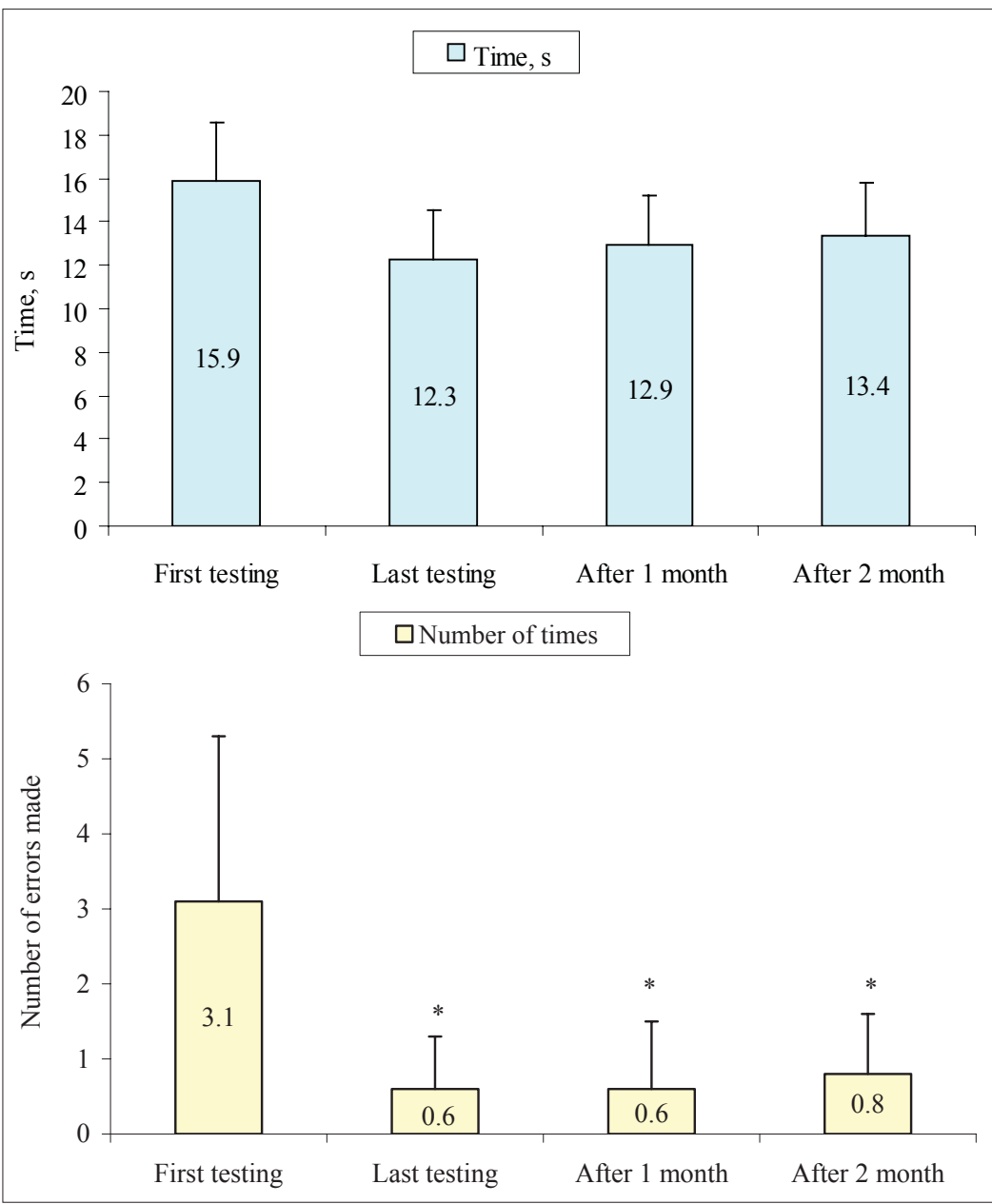

Fig. 7. The indices of stability of mastering dribbling the ball in the first group of parametric teaching

Note. * $-\mathrm{p}<0.05$ compared to the average results of the first testing. 
Fig. 8. The quantitative indices of application under new movements learnt circumstances when performing a lay-up shot in groups of different teaching
Note. *- $p<0.05$ compared to the indices of standard teaching group in 1 month.

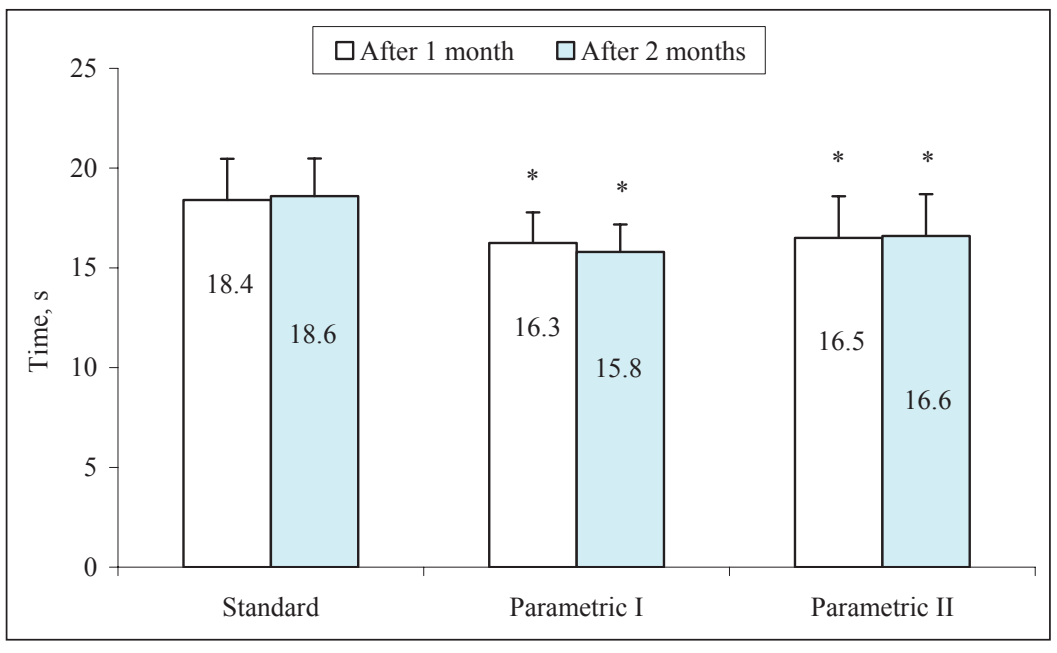

Fig. 9. The qualitative indices of application movements learnt under new circumstances when performing a lay-up shot in groups of different teaching

Note. $*-p<0.05$ compared to the indices of standard teaching group in 1 month; \# $-\mathrm{p}<0.05$ compared to the indices of standard teaching group in 2 months.

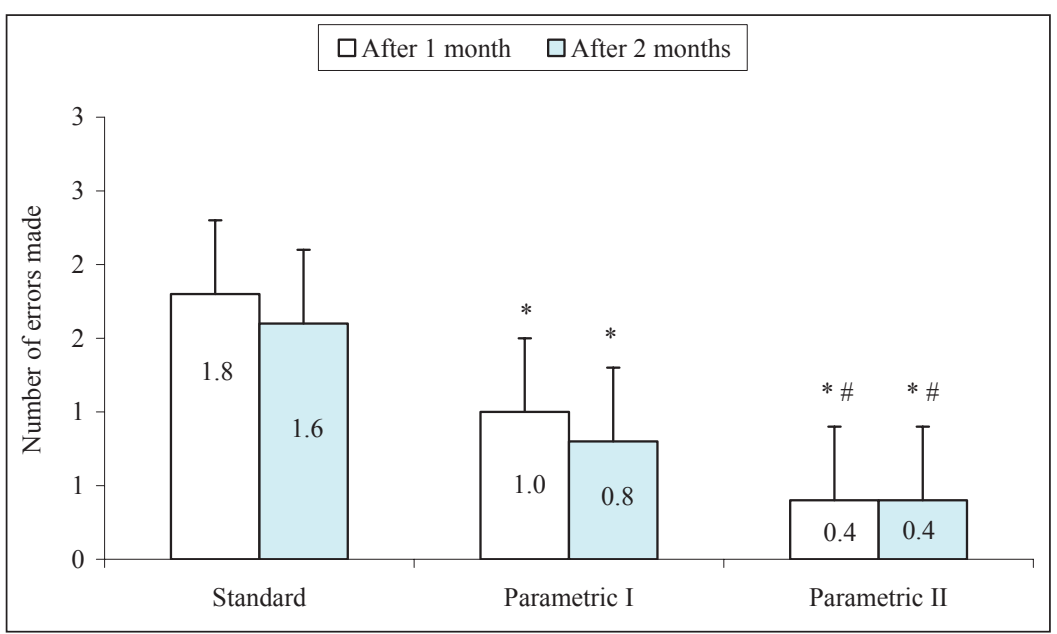

litative) after 1 and 2 months following the experiment were significantly higher of those children who had been taught new locomotive movements using the parametric teaching, i. e. under variable, more complicated conditions: the indices of testing of the children in the standard teaching group significantly $(\mathrm{p}<0.05)$ deteriorated (Fig. 6). The testing indices of children who had been learning new locomotive movements under variable conditions (using the parametric teaching, in the state of slight weariness) did not differ neither after one month nor two months: $p>0.05$ (Fig. 7).

The influence of teaching movements under standard and variable conditions on the retention of movements and application to the new circumstances (creativity)

Teaching complicated locomotive requiring high accuracy movements (performing a lay-up shot). The children of the parametric teaching groups retained better complicated locomotive movements which require high accuracy (performing a lay-up shot), when the direction of a movement and the position of shooting were altering and better applying them under new circumstances (Fig. 8, 9).

The qualitative indices of testing (Fig. 9) of both parametric teaching groups under new circumstances after 1 and 2 months following the pedagogic experiment statistically significantly $(p<0.05)$ differed from those of standard teaching group.

\section{DISCUSSION}

When determining and evaluating the children's movement abilities and changes in them, it is necessary to estimate not a separate movement or a part of it, but the whole. For that reason, tests of the kind of play, which include several movements (actions), describe the abilities of children's motor behaviour best (Bonacin et al., 2002). The important indices are the speed of performance of movements (quantitative indices), the accuracy of movements (qualitative indices), and coordination of the speed of performance and accuracy (Сковородникова, Голомазов, 2000). 
Discussion of the results of the development in mastering complicated movements. At the first stage of the pedagogical experiment, when teaching complicated movements that require accuracy (performing a set shot) either using the standard method (under standard conditions) or parametric method (in the state of slight weariness) when there is no change in the character of movements performed, and in outer parameters as well, the development of mastering, when evaluating the accuracy of a movement (quantitative indices) was adequate, although the average increase in the indices of the accuracy of movement in the children's group that was taught movements under standard conditions, was markedly better than that of the group that was taught using the parametric method. Starting with the 8-th lesson this increase in indices statistically significantly $(p<0.05)$ differed in favor of the group of standard teaching (Fig. 4). A number of authors (Magill, Hall, 1990; Shea, Kohl, 1991) made a conclusion on investigation of the effectiveness of teaching simple movements: children master new movements more quickly when they are taught using standard method than using the parametric method. This conclusion was confirmed at the first stage of the pedagogical experiment.

The ultimate indices of mastering new movements after teaching both groups of children were similar too: the indices of accuracy of movements taught, when compared to those of the initial testing, improved significantly $(\mathrm{p}<0.05)$.

Our experiment confirmed the theoretical statement (Rajtmajer, Vehovar, 2002) that it is possible to teach children new movements or actions (even quite complicated, requiring great accuracy) during a short period of time (2 months).

Variable conditions of teaching movement, when just the position of performance of a movement was altering (the direction of throwing a ball), but not any other parameter, did not have any essential influence on the progress of children's mastering movements.

J. A. S. Kelso (1999) maintains that if there is a need to evaluate the development of mastering a new movement more objectively, it is necessary to evaluate the change in management of movement of every individual who took part in the survey, but not the indices of all group as a whole.

Although the results of our survey reflecting the development of mastering new movements and change, allow to state that there is a common tendency of the improvement in the indices when teaching movements using both standard and parametric methods, still the results highlighted some differences between children's individual properties and managing abilities of movements and the importance of those properties to the development of mastering new movements. Because of these differences the change in mastering movements is different, mastering movements is individual when teaching using both standard and parametric methods.

This happened due to the influence of a number of factors on the development of mastering new complicated movements: at the initial stages of learning, the factors were child's thinking, knowledge of the performance of a movement, his / her peculiarities (intellectual abilities), physical properties and abilities as well as individual psychomotor abilities (Ackerman, 1992; Magill, 1997).

Discussion of the research results on stability of complicated movements. If there is a need to check the retention of movements learned and their reconstruction, i. e. the stability of new movements, it is purposeful to apply the same tests after some time (in our case in one and two months). If the movements and actions are performed with the same quality as they were at the end of the experiment, i. e. the movements are learned, the actions are stable, such movements are retained by children for a longer time (Schmidt, Wrisberg, 2000).

The indices of stability of complicated locomotive movements and actions learned (dribbling a ball) were similar to teaching complicated movements which require accuracy. During this process both quantitative and qualitative indices of testing in 1 and 2 months after the experiment higher statistically significantly of those children who were learning new locomotive movements using parametric method, i. e. under variable, more complicated conditions. The indices of testing children in the group of standard teaching deteriorated significantly $(\mathrm{p}<0.05)$ after the experiment (Fig. 6), whereas these testing indices of the children who were taught new locomotive movements under variable conditions (parametric method) did not differ neither in one nor two months: $p>0.05$ (Fig. 7).

Our study showed that girls and boys aged $8-10$ years can be taught, and the results achieved can be good, when teaching complicated actions and combinations, which require great accuracy, applying both standard and parametric 
teaching methods, since the children of certain age are already capable to carry out the provision of one of the most important complicated movements and actions (especially with a ball): coordinate the velocity of movement and accuracy. Yet the parametric teaching of new complicated movements and actions is more effective for the stability of the movements learned (Сковородникова, Голомазов, 2000; Rajtmajer, Vehovar, 2002).

Discussion on the results of the study of the influence on creativity of the movements learnt when teaching complicated movements under standard and variable conditions. R. A. Schmidt (1999) maintains that the most important goal of teaching and improving movements is the extension of child's inner abilities, so that he / she could perform different movements and actions in different situations in the future, i. e. to apply movements learned creatively.

When determining and evaluating children's movement abilities and performance of a movement under altering parameter conditions, under new circumstances, it is purposeful to evaluate not just separate movements but a whole. For that reason the tests of kind of play, when several technical actions are performed, reflect the abilities of children movements perfectly (Bonacin et al., 2002).

The children in the parametric teaching group in a new situation better applied complicated locomotive movements which require great accuracy (performing a lay-up shot after dribbling), when movement direction was altering - the position from which the ball was being thrown, and they retained those movements better as well. The average quantitative indices of testing (the period of testing) in both groups of parametric teaching statistically significantly $(\mathrm{p}<0.05)$ differed from those in standard teaching group. The same results were obtained for the qualitative indices of testing (Fig. 9).

The results of our survey essentially coincide with those received by many authors who carried out a lot of studies on children's possibilities and abilities to recollect and apply simple movements learned under new circumstances. These authors maintain that the parametric teaching of movements (under variable conditions) is very important when there is a need to construct schemes of performance of a movement (Schmidt, 1991; Skurvydas, 1998) and teaching movements under variable conditions allows children to learn more diverse movements and develop abilities to adapt to new circumstances, thus children master the new movements more quickly (Wrisberg, 1991).

\section{CONCLUSIONS}

1. The more relatively complicated movements and actions are taught the less difference between efficiency of standard teaching (in standard conditions) and parametric teaching (in variable conditions) is observed:

- when teaching complicated movements requiring accuracy using both standard and parametric method (outer parameters are constant, but inner obstacles exist), development and level of mastering are adequate;

- when teaching complicated, locomotive movements, the children in standard teaching group master the movements more rapidly;

- when teaching complicated, high accuracy requiring combinations of locomotive movements under standard and variable (parametric teaching) conditions, the indices of development of mastering did not differ essentially.

2. The children in standard and parametric teaching groups retained and reproduced (after 1 and 2 months) complicated movements of different degree of complexity in a different way:

- the children who had been taught under variable conditions (parametric teaching) markedly better retained and reproduced both complicated locomotive and complicated locomotive movements requiring accuracy;

- the children of parametric teaching groups who had been taught the same movements and their combinations under conditions of change in parameters of high degree, better retained and reproduced the movements than the children in other parametric teaching groups.

3. The efficiency of standard and parametric teaching of complicated movements for children's abilities to retain them for a longer period of time, reproduce and apply them under new circumstances - creativity of movements - depends on the character of the circumstances changed:

- the children in both standard and parametric teaching groups equally well retained and applied complicated movements requiring accuracy under new conditions after the change in outer parameters - direction or 
distance, but not altering the structure of movements;

- the children in parametric teaching groups better retained and reproduced movements under the new circumstances previously learnt which were complicated locomotive ones (requiring high accuracy) when the structure of a movement was altering and the necessity to make a choice existed.

\title{
REFERENCES
}

Ackerman, P. L. (1992). Predicting individual differences in complex skill asquisition: Dynamics of ability determinants. Journal of Applied Psychology, 77, 598-614.

Adaškevičienè, E. (1994). Vaiku fizinio ugdymo pedagogika. Vilnius: Egalda.

Bonacin, D., Pažanin, R., Katiae, R. (2002). Development of the coordination integration in boys aged 7-9 years: Sixth International Scientific Congress "Modern Olympic Sport and Sport for All", Warsaw, June 6-9 (pp. 649-650).

Dolonec, M., Pistotnik, B., Pinter, S. (2002). Correlation between co-ordination and cognitive abilities of girls 7 to 11 years of age: 3-rd International Scientific Conference "Kinesiology New Perspective”. Proceedings Book. Croatija, Opatija, 200209 25-29.

Jacoby, L. L., Bjork, R. A., Kelley, C. M. (1994). Illusions of comprehensions and competence. In D. Druckman and R. A. Bjork (Eds.), Learning, Remembering, Believing: Enhancing Human Performance (pp. 57-80). Washington: National Academy Press.

Kelso, J. A. S. (1999). Dynamic Patterns: The Self-organisation of Brain and Behavior. Massachusetts Institute of Technology.

Magill, R. A., Hall, K. G. (1990). A review of the contextual interference effect in motor skill acquisition. Human Movement Science, 9, 241-289.

Magill, R. A. (1997). Motor Learning: Concepts and Applications. Dubuque: Me Graw Hill.
Rajtmajer, D., Vehovar, M. (2002). Early learning of complex motor structures: 3-rd International Scientific Conference "Kinesiology New Perspectives". Proceedings Book. 200209 25-29. Opatija, Croatija.

Schmidt, R. A., Lee, T. D. (1999). Motor Control and Learning. USA: Human Kinetics.

Schmidt, R. A. (1988). Motor Control and Learning (A Behavioral Emphasis). Human Kinetics.

Schmidt, R. A. (1991). Motor Learning and Performance. From Principle to Performance. Human Kinetics.

Schmidt, R. A., Wrisberg, C. A. (2000). Motor Learning and Performance. USA: Human Kinetics.

Shea, C. H., Kohl, R. M. (1991). Composition of practice: Influence on the retention of motor skills. Research Quarterly for Exercise and Sport, 62, 187-195.

Skurvydas, A. (1998). Judesiu valdymo ir sporto fiziologijos pagrindai. Kaunas: LKKI.

Skurvydas, A., Gedvilas, V. (2000). Fiziniu ypatybiu lavinimo teorija ir metodika. Kaunas: LKKA.

Wrisberg, C. A. (1991). A field test of the effect of contextual variety during skill acquisition. Journal of Teaching in Physical Education, 11, 21-30.

Сковородникова, Н. В., Голомазов, С. В. (2000). Возрастная динамика проявления быстроты и целевой точности школьников и юных баскетболистов. Физическая культура, 1, 2-5.

\section{JAUNESNIOJO MOKYKLINIO AMŽIAUS VAIKŲ SUDE்TINGŲ JUDESIŲ IŠMOKIMO İERTINIMAS TAIKANT PARAMETRINI MOKYMĄ}

\author{
Rima Bakienè \\ Lietuvos kūno kultūros akademija, Kaunas, Lietuva
}

\section{SANTRAUKA}

Suvokus, kad judesiu, veiksmų išmokimas veiksmingas tik tada, kai išmoktą judesį, veiksmą vaikas geba taikyti naujomis sąlygomis, kai igytas igūdis ilgai atsimenamas, patvarus, buvo suformuluotas parametrinio judesių mokymo apibrèžimas (Schmidt, 1988, 1991, 1999; Skurvydas, 1998; Skurvydas, Gedvilas, 2000). Parametrinis mokymas - tai judesių, veiksmų, jų derinių mokymo būdas nuolat keičiant judesių mokymo kiekybinius dydžius (nuotolị, kryptị ir kt.), ivveikiant išorini (kliūtis, varžovą) ir vidini (nuovargị, jaudinimąsi) pasipriešinimą. Tyrimo tikslas - nustatyti ir įvertinti jaunesniojo mokyklinio amžiaus vaikų sudètingu judesių išmokimo veiksmingumą tokių judesių tikslumui, patvarumui, kūrybingam jų atgaminimui taikant parametrini judesių mokymą. Pedagoginio eksperimento metu buvo tiriamos trys mokinių klasės (grupės): 
kontrolinè ir dvi eksperimentinès. Kontrolinè moksleivių grupe - tai standartinio mokymo vaiku grupè, o dvi eksperimentinès - pirma ir antra parametrinio mokymo grupè, iš viso $(n=67)$ tiriamuju. Standartinio mokymo moksleiviu grupe per kūno kultūros pamokas buvo mokoma naujų sudètingų judesių standartiniu būdu. Pirma ir antra parametrinio mokymo grupè naujų sudètingų judesių mokèsi parametriniu būdu. Visais trim mokymo etapais sudarytu pratimu programa buvo taikoma $7-8$ savaites. Tuo metu buvo stebimas standartinio ir parametrinio mokymo grupès moksleivių naujų judesių išmokimo vyksmas. Paskui 2 mènesius buvo stebimas eksperimente taikyto standartinio ir parametrinio mokymo veiksmingumas, t. y. gebejjimas kuo ilgiau atsiminti išmoktus judesius. Galima daryti išvadas, kad standartinio ir parametrinio mokymo veiksmingumas judesių išmokimo vyksmui yra skirtingas: kuo santykiškai sudètingesnių judesių, jų derinių mokoma, tuo standartinio ir parametrinio mokymo veiksmingumo skirtumas judesių išmokimo vyksmui mažèja; mokant sudėtingų, tikslumo reikalaujančiu judesių standartiniu ir parametriniu būdu, išmokimo vyksmas ir lygis yra adekvatūs; mokant sudètingesnių lokomocinių judesių, sparčiau juos i̇valdo standartinio mokymo grupès vaikai; mokant sudètingiausių, didelio tikslumo reikalaujančių lokomocinių judesių derinių standartinėmis ir kintamomis sąlygomis, išmokimo vyksmo rodikliai iš esmès nesiskiria.

Ivairaus sudètingumo judesius, jų derinius standartinio ir parametrinio mokymo grupių vaikai atsiminè ir atgamino (po 1 ir 2 mèn.) skirtingai: tiek sudètingus judesius, tiek dar sudètingesnius lokomocinius judesius kur kas geriau atsiminè ir atgamino vaikai, kurie mokèsi ju kintamomis sąlygomis; parametrinio mokymo grupių vaikai, kurie mokèsi esant didelei parametrų kaitai, atsiminè juos ir atgamino geriau už kitų parametrinio mokymo grupių vaikus.

Standartinio ir parametrinio sudètingu judesių mokymo veiksmingumas vaiku gebejjimui ilgiau atsiminti, atgaminti ir pritaikyti anksčiau išmoktus judesius, jų derinius naujomis sąlygomis — judesių kūrybingumui — priklauso nuo pasikeitusių sąlygų: sudètingesnius ir sudètingiausius lokomocinius judesius naujomis sąlygomis, kintant judesiu struktūrai, esant ju pasirinkimo būtinybei, kur kas geriau atsiminé, atgamino ir pritaikè parametrinio mokymo grupių vaikai.

Raktažodžiai: parametrinis mokymas, vaikų mokymas standartinėmis ir kintamomis sąlygomis, jaunesnysis mokyklinis amžius (8-10 metu).

Gauta 2007 m. lapkričio 13 d.

Received on November 13, 2007

Rima Bakienè

Priimta $2008 \mathrm{~m}$. vasario $20 \mathrm{~d}$.

Accepted on February 20, 2008

Lithuanian Academy of Physical Education

(Lietuvos kūno kultūros akademija)

Sporto str. 6, LT-44221 Kaunas

Lithuania (Lieuva)

Tel +37061828806

E-mail r.bakiene@1kka.lt 